\title{
INCELEME YAZISI
}

\section{AĞIR AKUT PANKREATITTE CERRAHİ TEDAVININ SORUNLARI(*)}

\section{DROBLEMS OF SURGICAL TREATMENT IN SEVERE ACUTE PANCREATITIS}

Ali MENTEŞ

\section{SUMIMARY}

The aim in this review article is to discuss acute pancreatitis both interms of its nomenclature and its treatment alternatives, and to define the limits of a new loase for a novel understanding of the disease.

(Keywords: Classification, Pancreas, Prognosis)

\section{ÖZET}

Bu yazıda sık rastalanan bir sindirim sistemi hastalığı olan akut pankreatit gerek terimlendirilmesi, gerekse tedavi seçeneklerindeki sorunsallıklar çerçevesinde irdelenmekte, hastalığın çeşitli açılardan yeni bir tabana oturtulması için bir alt yapı oluşturulmaya çalışılmaktadır.

(Anahtar Sözcükler: Pankreas, Prognoz, Sinflama)

\footnotetext{
Genel Cerrahi ABD Hepatobilier Cerrahi Birimi (Prof.Dr.A Mentes) Ege Tıp Fakültesi 35100 Bornova - IZMiR

* 19 Ekim 2001 tarihinde Istanbul, 16 Ocak 2002 tarihinde Bursa ve 29 Ocak 2002 tarihinde Izmir"de yapılan konuşmaların metnidir.
} 
Akut pankreatit başlangiçta bütün başvuru şekilleriyle tek bir hastalik olarak tanmmlanmış; büyük ölçüde yaşam destek bilimlerinde o günlerde sahip olunan olanaklarm da smmliliğ nedeniyle tedavi standardi hastalarm konservatif bir tutumla ele almması olmuştur. Bu tutumun, yaşam destek olanaklarındaki olağanüstü gelişmelere karşin bugün de hastalarin büyük çoğunluğu bakımından geçerli olduğunu biliyoruz. Aradaki fark gündeş kabulümüzün, başlangıçtaki teslim olmuşluğa göre, beraberinde hem hastalar, hem de doktorlar bakimmdan ödenmiş yüksek maliyete sahip karmaşık bir süreç sonunda oluşmasidir(1). Ancak geçerli toptancı bakısla akut pankreatit, beraberinde proteolitik enzimlerin kendini hasarlayıc (autodestructive) sonuçarı olsun ya da olmasin, pankreasin her düzeyde akut intersitisiyel enflamasyonu olarak kabul edildiği taktirde, anlayıș ve tedavisi konusunda yillar içinde elde edilmiş olan ve gelen dönemde de elde edilebilecek bir çok kazanuma rağmen sorunlu bir tablo olarak kalacaktır. Bunun en önemli nedeni, akut pankreatit konusundaki her soruya verilebilecek tek yanıt olmamasıdır. Pankreatit tablosu, o hastadaki klinik önemine; doku hasarının hastalığın doğal evrimi içinde ne kadar belirleyici olduğuna ve hastalarm yaşamlarma yönelmiş olan tehdidin mutlaklığına göre daraltıldıkça bu yanıt değişecektir. Buna karşın bugünün egemen anlayışı pankreasin her türlü akut interstisyel enflamasyonunu bir bütün olarak değerlendirmek olduğundan, her hangi iki meslektaşm -enflamasyonu hangi doku yanitı düzeyide algıladıklarına bağlı olarak-akut pankreatit konusunda diyalog sürdürmeleri ancak zorlukla mümkün olabilmektedir. Bu bakımdan akut pankreatite yönelik cerrahinin ilk ve önemli sorununun nomenklatür (terim listesi)'e ilişkin olduğunu itiraf etmek gerekir.

\section{Akut Pankreatit Nomenklatürü}

Akut pankreatitin alglanmasındaki değişim süreci içinde nomenklatürün (terim listesi) gözden geçirildiği ve yeniden gözden geçirildiği birçok durum buIunmasina rağmen, genelllikle bu konudaki köșe tașinı 1992 Atlanta Sem- pozyumunun (2) oluşturduğgu kabul ediliz. $\mathrm{Bu}$ toplantıda pankreas nekrozu, enfekte ve steril nekroz, pankreas flegmonu, pankreas apsesi, pankreatik sepsis, pankreas çevresi sıvı birikintileri ve psödokist, katılanların üzerinde uzlaştığı ayrı ve özgül kavramlar olarak tanımlanmıştır. Anılan bu kavramlarin gerek pankreatit sistematiği, gerekse klinik algilanması bakımından yerleştiğini kabul etmek gerekir. Bu nomenklatürle birlikte gelen en önemli epistemolojik (bilgi bilim) katkıysa, eskinin klinik şiddetliliği kendi başına yansitmayan ödematöz, hemorajik, nekrotizan gibi histo-morfolojik sistematizasyon yerine artık hafif ilimlı (=mild) ya da ağır akut pankreatitten söz edilmekte olması; hastalığın sistematizasyonunun klinik-prognostik bir nitelik kazanmasıdır. Genel anlamiyla hastalarin \%75-80'inde görülen tablo hafif ( 1 limli) pankreatittir ve bu gurupta hastalik mortalitesi \%2'nin altında kabul edilmektedir. Kalan \%20-25 oranindaki hasta ise ortalama \%25 (\%15\%30) mortalite olasılığıyla seyreden ağır akut pankreatitlidir (3). Tablonun iki şekli arasindaki en önemli morfolojik fark nekroz varlığı ve yaygınlığıdır. Buna göre ağır akut pankreatitte, interstisyel ödem içerisinde ancak birkaç geniş nekroz alanı bulunabilir. Bu nekrozun bezin herhangi bir görüntüleme işlemindeki hacminin $\% 50$ 'si genişliğinde ve enfekte olması hastalığın en sorunlu ve ciddi şeklini temsil eder ki bu, pankreatit sorunsalmm da en önemli kısminı oluşturur.

Bradley (2), Atlanta uzlaşma toplantısının sonuç bildirgesini yayınladığında, bu uzlaşmanın son olmayabileceğini kaydetmekle öngörülü bir tutum sergilemiştir. Çünkü Atlanta uzlaşmasının tartışmasız tek katkısı hastalığın algılanmasını saf klinik bir temele oturtması olmuştur Üzerinde uzlaşlan geçerli tanımlamaların açıta biraktı̆̆ı iki ana durum, varolan toptancı tanımlamanın gerçeğe aykırılığı karşısında, hangi özgül ve dar çerçevenin pankreatit olarak tanımlanması gerektiği ile ağır genel başlığı içinde toparlanan doku hasarları bütününün tektip olup olmadığıdır.

Sadece nomenklatür açısından değil, epistemoloji açısından da en önemli ge- 
reksinim; pankreastaki hangi tür enflamatuar yanıtın akut pankreatit olacağmin belirlenmesidir. Akut pankreatit üzerine yapılan deneysel çalışmaların büyük çoğunluğunda kullanılan pankreatit tetikleyicisinin bir kolesistokinin analogu olan serulein oluşu, tek başına bile, konunun algılanmasmin etkileyen çok önemli bir saptiric durumundadir. Zira iyi bilinmektedir ki, serulein ile kısa süreli, dokuda ödematöz bir yanittan ileriye gitmeyen, hemen kesin olarak öldürücülüğü olmayan ve başka tetikleyicilerle birlikte kullanılmak suretiyle deney koşulları özellikle kurgulanmadığı taktirde $(4,5)$, geride iz birakmayan bir akut pankreatit oluşmaktadır. Serulein uyarısiyla pankreasta oluşturulan bu tür akut enflamatuar yanitin limli akut penkreatitle özdeşleştirilmesi, gerçekte pankreatiti alglamayı ve asıl akut pankreatit tablosunu tektip evrelere ayırmayı zorlaştırmaktadir. Kolesistokinin, sonuç olarak pek çok uyarım altında işlevsellik göstermektedir. Serulein ile oluşturulan deneysel pankreas yanitı gerçekten klinik anlamda geçerli olsa ve llımlı da olsa akut penkreatit oluşturabilseydi, in-vivo yaşamda kolesistokinin aktive olduğu her koşulda pankreatit oluşması gerekirdi. Oysă biliyoruz ki, her zaman böyle olmamaktadır. Ayn durum oposum gibi deney hayvanlarnda bilyopankreatik kanal bağlanmasinin erken evrelerinde oluşan ödematöz pankreas cevabmnn(1) insan koledok kanah tikanmasina yansimamasiyla da gözlenebilir. Keza, viral hepatitin de akut evrelerinde gözlenen serum amilaz yükselmesi (2) pankreasta oluşan bir hasari telkin eder yargısı doğru değildir.

Tipkı ılımlı akut pankreatitin en büyük etyolojik etmeni olan safra yolu taşlarindaki gibi, bu tablolarin tümünde var olan ortak durum, bir bütünlük içinde olan hepatopankreatobiliyer sistemin herhangi bir noktasinda ortaya çıan yerel homeostazis, değișimin pankreas tarafindan bir taciz olarak algılanması ve buna karssı, enflamatuar yanitla kariştirlan bir tepki olarak değerlendirilmelidir. Dolayısıyla akut pankreatit nomenklatür ve epistemolojisinde üzerine gidilerek açıklığı kavuşturulması gereken en önemli kavram pankreasa tacizinin (pancreatic insult), pankreas hasarmdan (pancreatic injury) ayırt edilmesidir. Şu durumda bile akut pankreatit oluşması için saldırının varliğının tek başına yeterli olmadığını, ister membran işlevlerinin bozulması (3), pankreasta bir enzimatik zincir reaksiyonu başlaması (4) ya da lizozom, mitokondriya (5) ve/veya pankreas enerji zincirinde hasarlanma (6) olması gerektiğini düşündüren hayli veri mevcuttur. Pankreasa taciz kavramı açıkça tanımlanıp, sınırları belirlendiğinde, olasılıkla bugün ılımlı akut pankreatit olarak nitelediğimiz ve hastaneye yatırmak gereği bile duymadiğımız ya da yatsalar bile her hangi bir özgül önlem alınmaksızm bir iki günde kendiliğinden iyileşen hastalar pankreatit tabanının dişına çıkarılacaklar ve ılımlı akut pankreatitin sinirları da yeniden tanimlanmak zorunda kalacaktır. Bu durumda, yine muhtemelen, steril nekrozlu ağır pankreatit olarak kabul ettiğimiz hasta gurubu 1 limli pankreatitlileri oluşturacak; bu da hem iç geçişleri olan dinamik seyirli bu hastalikta yaşamdaki gerçekliğin algiya ve klinik uygulamaya da birebir yansımasını sağlayacak; hem de şu andaki haliyle her orandaki steril nekrozluları, enfekte nekrozluları, nekrozları pankreasta ve/ya da çevrel dokuda yoğunlaşanları ve fulminan seyirlileri bir bütünmüş gibi kabul ederek ağır akut pankreatit başlığı altına irdelemenin getirdiği çıkmazların aşılmasına yardım edecektir.

\section{Klinik Seyir Kestirimi}

Akut pankreatitin dinamik ve iç geçişleri olan bir klinik tablo oluşu yaşamun bize öğrettiği bir gerçektir. Bu bakımdan, herhangi bir hastada olası prognozun kural olarak bilinememesi, hangi hastalarda yaşamın özellikle tehdit altında olduğunun iş işten geçmeden belirlenmesi gereksinmesini doğurmuştur. Ranson önderliğinde 1974'den başlayarak geliştirilen risk kestirim ölçütleri (Tablo 1) akut pankreatite rasyonel bir klinik yaklaşım oluşmasinda etkili olmuştur $(7,8)$. Bu ölçütler zaman içinde bazen değiştirilmiş, bazen yeni ölçütlerin rekabetiyle karşı- 
laşmıştir. Bu gurupta yer alan beden kütle indeksi², CRP yükselmesi, şişmanlık varlığı, periton yıkama sivisındaki tetkikler, tek ya da çift taraflı plöral sıvı birikimi gibi göstergeler akut pankreatitin şiddeti hakkinda sadece tek boyutlu bilgi sağlarlar. Oysa, Ranson ölçütleri dahil, APACHE 2, Imrie (Glascow), modifiye Glascow gibi risk kestirim ölçütlerinin tümündeki ortak payda pankreatite eşlik eden pankreas dışı organ yanıtıdır. Bu yanıt ne kadar çok sayıda organı etkilemiş ve etki organin ne kadar bozulmasina yol açmışsa risk o ölçüde artmaktadır.

TABLO 1: Akut pankretitte Ranson'un şiddet kestirim ölçütleri

\begin{tabular}{ll}
\hline Bașvuruda & Ilk 48 saatte \\
Yaș 55 & Hct $\% 10 \S$ \\
Lökosit $16.000 / \mathrm{mm} 3$ & Üre $\% 50 \mathrm{mg}$ \\
Kan Şekeri $200 \mathrm{mg} / \mathrm{dl}$ & Ca++ $\% 8 \mathrm{mg}$ \\
LDH 350IU/L & pO2 $60 \mathrm{~mm} \mathrm{Hg}$ \\
SGOT 250IU/L & Baz eksikliği $4 \mathrm{mEq} / \mathrm{L}$ \\
& Sıvı açığı $6000 \mathrm{ml}$ \\
\hline
\end{tabular}

10-2 ölçüt: ılımlı; >2 ölçüt: ağır klinik seyir beklentisi)

$\mathrm{Bu}$ ortak paydayı algılamak önemlidir çünkü, her ne kadar tanımlanmış kestirim ölçütlerinin neredeyse birebir belirlenmiş klinik riskleriyle tam uyumlu olmasada da, tekil hastalarda klinisyenlerin kendi kestirimlerini biçimlendirmelerine yardımcı olabilir. Zira bilinen kestirim şablonlarının hemen tümünün doğru ve etkin kullanım açısından kısıtlamaları bulunmaktadır. Ranson ölçütlerinin belirlenmesi 48 saate gereksinmekte olup, daha çok alkolik pankreatitli hastalar göz önünde tutularak tasarlanmıştır. Imrie'nin tanımladığı ölçütlerde ise alkolik ve biliyer pankreaitler göz önünde tutulmuş, ancak kullanım tercihinde ikinci planda kalmıştır. APACHE 2 kestirimi çok ayrıntılı ve bu nedenle özellikle kisitlı olanaklı hastanelerde uygulanma geçerliliği son derece sinırlı bir fizyolojik değerlendirme sistemidir. Bu bakimdan ortak paydanin pankreas dişı orgản ve/veya sistem yetmazliğinin sinırlarının aranması olduğunu bilmek önem taşımaktadır. ALT ya da AST aracılığıyla karaciğer parankim yanıtı, kan şekeri aracılığıyla mitokondrial karaciğer yanitı yanı sira glukoz homeostazisinin kontrolu, lökosit sayısı aracılığıyla bağışıklık sistemi ve enfeksiyon cevabı, kan üresi aracılığıyla böbrek yanıtı, hematokrit aracılığıyla hipovolemik yanıt her yerde kolaylıkla elde edilebilir ölçütlerdir. Genel kabul, pankreas dişında ikiden fazla organ yanıtındaki bozulmanın ağır bir klinik seyri işaret etmesi yönündedir. Bu hastalar, enfekte geniş pankreas nekrozuna sahip oldukları gösterilmese de cerrahi girişim adayı olarak kabul edilmelidirler. $\mathrm{Ne}$ var ki klinik-kimyasal risk kestirimi ölçütleri de kusurdan arınmış değildir. Bu tür kestirimin taşıdığı en önemli sakınca değerlendirmelerin, saptanan organ/sistem yetmezliği yanıtının sadece varlığını kayda alması, yetmezliğin ağırlığının ya da hangi organ veya sistemin ne şiddetteki yetersizliğinin, ne gibi bir risk artımı içerdiğini yanıtlayamamasıdır.

1980'li yllardan başlayarak görüntüleme yöntemlerinde ortaya çıkan devrimsel gelişmeler, o zamana kadar ancak dolaylı olarak görüntülenebilen pankreas lezyonlarına karşı klinisyenin egemenliğini çok arttırmıştır. Bu çerçevede akut pankreatite radyolojik yaklaşım da değişmiş ve özellikle Balthazar ve ark (10) tarafindan önerilen kestirim ölçütleri yaygınlık kazanmistir. Balthazar ve ark, kontras (1a zenginleştirilmiş/) eklenmiş bilgisayarlı tomografi (BT; KEBT) ile saptanan siddet indeksinin (BTŞİ) 0-3 arasinda olduğu hastalarda mortalite olasılığını \%3, morbidite olasılığını \%8; indeksin 7-10 arasinda olduğu hastalarda mortalite olasılığını \%17 ve morbidite olasılığını \%92 olarak bildirmişlerdir. Daha sonraki çalışmalarda da BTŞİ'i 5 olanlara ölüm $(\mathrm{p}=0.0005)$, uzun hastane yatışı $(0.0001)$ arasında açık bir uyum gösterilmiştir. BTŞİ'i 5 olanların diğerlerine göre ölüm risklerinin 8; hastanede yattıkları sürenin uzamasinın 17; nekrozektomi geçirme olasılıklarının 10 kat arttığı hesaplanmiştır (11). Balthazar'ın önerdiği şiddet skorlaması (tablo 2) gerek bezin radyolojik görünümünü, gerekse enflamasyonun ve nekrozun şiddetini içermesi dolayısıyla 
kullanışhı̆ğı yüksek olmak yanında, klinik-biyokimyasal kestirimin taşıdığ hasar şiddeti/prognoz uyumu bağlantısını da göz önünde bulundurmaktadır. Böylelikle klinisyen suk BT değerlendirmeleriyle hastalığn gidişini izleyebilme ve şiddet indeks skoru yükselmeye başlayınca girişim zamanınin geldiğine karar verebilecektir $\mathrm{Bu}$ verilerin kliniğe henüz sunulduğu dönemde radyologlarm da cerraha uyumları yüksek olmuş ve sık BT kontrollarıyla ağır akut pankreatitli hastalarm tedavi süreçleri dinamik bir işbirliği alanı olarak gözükmüştür. Ne var ki, ilk heyecan yatıştığında radyologların hevesleri sönmüş ve ağır akut pankreatitli hastaların klinik izlemlerinde tekrarlanan KEBT yerine ultrasonun kullanmmin gerekliliği vurgulanur olmuştur. Bu arada inceleme sirasmda kullanilan iyodinize kontrast maddelerin de özellikle dehidrate hastalarda nefrotoksik potansiyele sahip oldukları öne çkarılmıştır. Ağır akut pankreatitli hastalarm büyülk çoğunlukla zaten Sıvı açığı ve böbrek yetmezliği riskinde olmaları nedeniyle KEBT'nin, bir başlangıç (base-line) görüntüsü sağladiktan sonraki kullanmm böylelikle genellikle çok kısıtlanmıştur. Ikinci KEBT için istekte buIunmanm uygun zamanının, arada düşmeyen yüksek ateş, dinmeyen ya da artan ağrı, ısrarlı hipotansiyon ya da hematokrit düşmeleri olmadıkça 10 günden önce olmadiğ belirtilmiştir (12). Bir süre sonra MR-görüntüleme yaygınlaştığında, nefrotoksisite potansiyeli taşımadığ tilerek $\mathrm{T} 1$ sekanslarla gadolinyumla arttırılmıs MR göruntülerinin kullanımı öne çıarılmaya başlanmıştır. KEBT şiddet skorlamasına dayanan Balthazar ölçütlerinin MR'la da kabaca karşlanabilir olduğunu düșünmek mantıklı gözükebilirse de net olarak ifade edilmiş değildir.

Yakm zamanda Paris kökenli bir prospektif calısma (3), radyologlarm seri KEBT incelemeleri uygulamaktaki isteksizliklerini net olarak yansıtmaktadır. Bu çalișmada KEBT'nin hastaneye kabulde Ranson ölçütlerinin $>2$ olduğu hastalarda uygulanmasi, bildirilen seride \%80 dolaymda olan diğerlerinde yapılmaması önerilmektedir. Ne var ki dizide Ranson ölçüt sayısı <2 olduğu halde iyi klinik sonuç alınmamış hastalar \%8 oranındadır. Çalışmacilar uygun bir dille bu azinlik gurubu için ek külfete girmenin gereksiz olduğunu ifade etmek yanında, KEBT ile bir hafta sonra yapilan ikincisi arasında tablolar1

TABLO 2: [Balthazar] Kontrast Eklenmiş Bilgisayarlı Tomografi (KEBT) ölçütleri

Enflamatuar Süreç:

Puan

Derece (Grade)

\begin{tabular}{llr}
\hline A Normal Pankreas & 0 \\
B Pankreasın fokal ya da diffüz büyümesi & 1 \\
C Peripankreatik enflamasyonla birlikte bezin anormal & \\
& görüntüde oluşu & 2 \\
D Tek yerleşimle sıvı birikintisi & 3 \\
E Pankreas bitişiğinde iki ya da fazla sıvı birikinti odağı ve/ & 4
\end{tabular}

Nekroz:

Yok

$\% 30^{2}$ dan az

$\% 30-50$

$\% 50$ 'den fazla

[BT Şiddet İndeksi=Enflamatuar süreç puanı+nekroz puaniı] [Mortalite olasılığı: 0-3 puan $=\% 3 ; 7-10$ puan $=\% 17$ ]

karıșım gösteren 24 hastadan 22'sinde (\%92) biyokimyasal verilerin bir şekilde klinik kuşkuya yol açmiş olmaları sebebiyle bu tür hastalarda da KEBT'nin tekrarlanmasinın yerinin sinırlı olduğunu kaydetmektedirler. Akut pankreatitin dinamik bir hastalık süreci olduğu, başlangıçta nekrozun olmaması ya da $<\% 30$ olmasina karssilık, her zaman $>\% 50$ ye ulaşabileceği bilinmesine ve anilan çalişmada da Balthazar $D$ ve $E$ görüntüleri eşliğinde $>\% 50$ nekrozu bulunan hastalarda prognozun belirgin olarak kötü olduğu belirtilmesine rağmen, 710 günden sik KEBT kontrolü yerine, hastalarin ezici çoğunluğunda tetkikten hemen tümüyle vazgeçilmesinin önerilmesini "profesyonel ilginin kaybolmasi"ndan başka bir şekilde açıklamak olası değilir. Lökosit sintigrafisi (14) gibi yöntemlerle de pankreatit şiddetinin doğru olarak izlenebileceği yönünde bildirim olmasina 
rağmen, nekroz ve pankreas dışı sıvı birikintileri ile klinik parametreler arasında bir uyum bulunmasinin zorunlu olmaması $(15,16)$ ve biyokimyasal testlerin yüksek "sinır" değerlerinde bile hastalık şiddetini göstermekteki kıymetlerinin çok sınırlı olması (17) yanı sura, pankreasın enfekte nekrozunu, hastada sepsis tablosu ortaya çımadan saptayabilmek için KEBT ve BT rehberliğinde ince iğne doku örneklerinden patojen izolasyonu (yayma) dişında yaygın ve güvenilir bir yöntem bulunmamaktadır. Kalfarentos ve ark, bu şekilde tekrarlanan ince iğne aspirasyonları ve enfekte nekroz saptananlarda açık debridman ve postoperatif lavajla kontrol gurubundaki $\% 26$ 'lik mortaliteyi \%8 dolayma indirebilmişlerdir.

\section{Cerrahi Girișim Endikasyonu}

Bu soruyu cevaplandırmanın çok kolay olduğu kanısındaki meslektaşlar için formülasyon oldukça kısa ve basit olacaktır. Ağır akut pankreatitte cerrahi nekrozektomi (debridman) ve peritoneal lavaj, enfekte nekrozu olan hastalarda, saptanir saptanmaz ve tercihan karın tekrarlanacak girişimler için paketlenip açı birakılarak yapılmalıdır. Bu önermenin kendi içinde doğruluğu çok açı olmakla birlikte, ne yazık ki klinik duruma tam bir uyumu olduğu söylenemez. Pankreas nekrozunun hastalarin ancak \%20 kadarinda geliştiği, bunlarm da \%60-70'inde steril kalmaya devam edebileceği ifade edilmiştir (19). Öte yandan pankreasta bakteri kolonizasyonu için iki olası yol bulunduğu deneysel olarak gösterilmiştir. Bunlar enterik mikroorganizmalarin mezenter lenf bezlerine translokasyonundan sonra hematojen yayılim ile bilyer kanaldan transduktal bulaşımdır (20). Özellikle Ulm gurubunun kabulü çerçevesinde, bu mekanizmalarla ağır akut pankreatitli hastalarm \%40-70'i tablonun başlangıcm izleyen üç hafta içinde enfekte nekroza dönüşmektedir (21). Nekrozun steril ya da enfekte oluş sıklığı üzerine hangi bakış açısı kabul edilirse edilsin, sonuçta toplam akut pankreatit havuzundaki hastalar arasinda enfekte pankreas nekrozu gelişenlerin oranının \%10'un bir miktar altında olduğu kabul edilmelidir. Bunlar arasında pankreasın anlamlı yüzdesini tutan nekrozlular daha da azınliktadir. Bu bakımdan biraz önceki önermenin aşır belirlemeci (determinist) bir yanıttan oluştuğu ve gerçek anlamda klinik sorunsala yanıt olmadığı belirgindir. Bir çok rastgele çalışma, ağır akut pankreatitli hastalarda koruyucu antibiyotik verilmesinin septik komplikasyonları anlamlı şekilde azalttığını göstermiştir. Yakın zamandaki bir çalişmada akut pankreatit sürecinde erken imipenem-silastin tedavisinin kontrollara oranla organ komplikasyonlarını ve cerrahi girişim gereği ciddi (ama istatiksel açıdan anlamsız) olarak azalttı̆̆ı, ölüm oranını da (yine istatistiklere yansımaksızın) yarıya indirdiği gösterilmiştir (5). Ne var ki, çalışmalarının çoğunda antibiyotik verilmesinin ölümcül üzerinde etkisi olmamıştır. Bunda enfekte nekrozun karış1k bir floraya sahip olması, kültürlerde üretilen mikroorganizmalarm $\% 10 \mathrm{kada}-$ runın çoğul-direnç taşıması yanında, önemli bir kisminin da profilakside kullanılan antibiyotiğe dirençli olması rol oynamakta olabilir (23). Öte yandan tüm nekrozlu hastalarda profilaktik antibiyotik uygulandiğında pankreas enfeksiyonunun karakteristiği de gram negatiften, gram pozitif ve mantar ağırlıklı bir floraya kadar değişmektedir (24). Anılan gerekçeler nedeniyle akut pankreatitli hastalarda erken antibiyotik profilaksisinin önemli bir yeri olmakla birlikte, bu yaklaşımın ancak steril nekrozlu hastalarda tedavi seçeneği olduğu; bu tür hastalarda antibiyotik yoğun koruyucu yaklaşıma sonuna kadar sadık kalınması gerektiği kabul edilebilir. Steril nekrozda cerrahi debridman (nekrozektomi) gereği bir istisna olarak nitelenebilir. Bu arada steril pankreas nekrozu olan hastalarin $\% 7$ kadarmin da, ağızdan beslenmenin bașlamasıyla birlikte yeniden beslenme pankreatiti adi verilen yeni bir atakla karşılaşılabileceği unutulmamalidir.

Cerrahi girişim kararinin sorunlu olduğu hastalar KEBT ile saptanan nekrozun \%30 olması nedeniyle ince iğne aspirasyonuna gerek duyulmayanlar, \%50 steril nekrozları olduğu saptanan ve koruyucu yaklaşılirken önlemlerin açık yetersizliği görülenler, cerrahi akut karın ya 
da sepsis gelişenler, en az 72 saat yoğun bakım desteğine rağmen klinik durumları israrla bozulanlarla bir ya da daha fazla organ ya da sistem yetersizliği gösterenlerdir $(25,26)$. Ağır akut pankreatittte kanıta dayalı tip uygulaması taraflarlarınin, tedavi avantaji konusunda herhangi bir A sinıfi kanıt bulunmadığinı belirtmek zorunda kaldikları (28) hastalar bu ara tablolardakilerdir. Enfekte nekrozun zamanında tanımmaması yüzünden geciktirilen cerrahi girişimin başarısızlığının altı çizilmiştir. Ayrıca en az bir seride, ister exken ister geç cerrahi uygulansin ölümlerin tümünün 70 yaşın üzerinde ve ideal yoğun bakım önlemlerinin başarısızlığı yüzünden cerrahi kararı verilenlerde oluştuğu gösterilmiştir (29). Belki de bu hastalardaki başarısız sonuçlardan pankreas kanal bütünlügünün bozulmasina bağh kaçaklar sorumludur; çünkü bu tür hastalarda nekroz gelişme olasılığının ve hastane kalıș uzamasınım, kanal kaçağı olmayanlara göre ortalama üç kat arttığ gösterilmiştir (30). Ne olursa olsun, bugün için net tedavi stratejisi çizilemeyen ve ağır akut pankreatiti tablosunun genel tedavi başarısım bulunduğu seviyeden yukarıya cekecek hastalar bu guruptakilerdir. Bu hastalarda esnek bir yaklaşım göstermek (31) gereklidir ve herhalde bu esneklik daha çok nekrozektomi ve/veya eksporasyon -lavaj kararını zamanında (ağır organ yetmezlikleri gelişmeden) vermeye odaklanmalidir.

\section{Cerrahi Girişim Tercihi}

Ağir akut pankreatitli hastalarda nekrozektomi için üç temel yol bulunmakla birlikte, tümünde geçerli ortak özellikler vardır. Öncelikle, pankreas hasarmna katkıda bulunmamak için keskin diseksiyondan kaçmmalı, nisbeten kolaylıkla ayrılan ölü dokular toplanmalıdır. Hastalığın başlangıç evrelerinde nekrotik dokular oldukça sert olup, çevre dokudan ayrım çok belirgin olmayabilir. Zamanla (en ideali 3-4) hafta içinde) kivaml ve sinirları netleşmiş bir nekroz gelişir. İkinci olarak, her hastada nekrozun istenen kıvama gelmesini beklemek mümkün olmayacağina göre görünürde tam bir nekrozektomi yapılmasına karşın, cerrahi girişimden sonra da nekroz gelişmeye devam edebileceği, bu nedenle tekrarlanan nekrozektomilere gerek duyulabileceği daha en başından hesaplanmalıdır. Üçüncü olarak da, pankreas nekrozu kadar, belki ondan da önemlisi her iki parakolik olukta ve retroperitoneal yumuşak dokuda gelişen nekrozun mortaliteye katkısıdır ki bu, kalın barsağin geniş olarak mobilizasyonunu ve retroperitoneal geniş debridman ve drenaj/lavajı gerekli kılar. Cerahi seçenekler sonradan karın kapatılarak nekrozektomi lojuna çok sayıda yumuşak dren konulup, nekrozektomiden arta kalan enfekte debrisin sürekli yıkamalarla almmasi ve debridman/nekrozektomi sonrası (yıkamalı ya da değil) karnin paketlenmesidir (32). Farkli hastaların değişik gereksinmelerine karşılık her üç yöntemin de kullanımda yeri olduğu kabul edilmelidir. Ne var ki, tümüyle pratik nedenlerle son seçeneğin (yani açlk paketlemenin) ek avantajı olduğu düşünülebilir. Bu avantaj özellikle fizyopatoloji temelinde değildir. Nekrozektomi gereği duyulan hastaların tedavi süreci içerisinde renekrozektomi sayısı genellikle ortalama 3 dolayında bildirilmekte (33), bu sayı daha yukarıya da çıkabilmektedir (3). Bu durumun ağır akut pankreatit konusunda deneyime sahip cerrahlar tarafindan iyi bilinmesine karşllık, deyim yerindeyse yoğun bakım biriminde tam anlamiyla dağılmış olarak yatan enfekte nekrozlu hastalara renekrozektomi yapilmasinin, özellikle sorumluluk yüklendiğini düşünmeyen cerrahlarca her firsat kullanilarak ertelenmekte, geciktirilmekte oluşu bir gerçektir. Kuramsal ifadeler ne olursa olsun, bu ağır ve dinamik hastalık sürecinde bu tür yaklaşım mortaliteyi arttırmakta, hastanın en yüksek cikarlarına hizmet etmemektedir. Bu bakımdan açık paketlemeli yaklaşımın, isteksiz cerrahı girişime zorlamakta ek bir katkısı olduğu düşünülebilir.

Tekrarlamalı nekrozektomide tek sorun cerrahin isteksizliği değildir. Önemli sorunlardan biri de hangi nekrozektominin o hastadaki sonuncu girişim olması gerektiğini kestirmektir. Kestirmeci bir yaklaşım sergileyerek, hastada herhangi bir nekrozun saptanamadiğı eksplorasyondan 
sonra karnın kapatılması savunulabilir ancak, özellikle kritik bir dengede bulunan hastada olmayan ya da önemsiz bir nekrotik doku parçası için kaçınılabilecek bir yeni girișim kararı almak ciddi bir sorumluluktur. Bu noktada alışılagelmiş nekroz saptama/değerlendirme ölçütleri yararsizdir.

\section{Nekrozun Seyrimin Kestirimi}

Bir çok çalışmacı pankreatitin klinik seyrini kestirmek bakımından kullanılabilir tek ölçütün, hastalığın ilk 24 saatinde yükselen IL-6 (Interlökin-6) düzeyleri olduğunu, bu ölçütün Ranson ya da APACHE 2 ölçütlerinden daha doğru kestirimci olduğunu düşünmektedir (35). Öte yandan, deneysel veri IL-1 reseptörleri aktivasyonunun pankreatit gelişmesi için zorunlu olmadiğı, ancak pankreas hasarının belirginleşmesi için gerekli olduğunu düşündürmektedir (36). Aslına bakılırsa, akut pankreatit tablosunda yer bulan doku belirleyicilerinin büyük çoğunluğu da bu iki interlökinden biri tarafindan tetiklenmektedir (37). Devam eden arayışlar bir yana (38), bu çevrede deneysel ya da klinik kullanımı olmuş belirleyiciler (sitokin temelli ya da değil) nötroofil elastaz, CRP, Tripsinojen aktivasyon peptidi

\section{KAYNAKLAR}

1. Mentes A, Yetkin E, Özgediz G, Akut pankreatitte cerrahi tedavini yeri, $T$ Gastroentoral Derg $1980 ; 1: 735-41$.

2. Bradley EL, A clinically based classification sustem for acute pancreatitis Arch Surg, 1993 ; 128 : $586-90$.

3. Imrie CW, Acute pancreatitis stratifying severity-how, and does it make a difference?, Contorvesies and Clinical Challenges in pancreatic Disease, AGA Postgraduate Course, New Orleans, 1998.

4. Schmidt J, Lewandrowski K, A better model of acute pancreatitis for evaluating therapy, Ann Surg. $1992 ; 215: 44-56$.

5. Schmidt J, Lewandrowski K, FernandezCastillo $C$ et al, Histopathologic correlates of serum amylase activity in acute experimental pancreatitis, Dig Dis Sci, 1992; 37 : 1426-33.

6. Lerch MM, Saluja AK-Dawra $R$ et al., Acute necrotizing pancreatitis in the Opossum: Earliest morphological changes involve acinar cells, Gastroenterology, 1992; $103: 205-1$.
(TAP), Pankretitle birlikte olan protein (PAP), TNF, ribonükleaz, $\alpha-2$ makrog-lobulin, fosfolipaz A, methemalbümin şeklinde siralanabilir. Bunlar arasında özellikle PAP, ancak pankreas hasarı olduktan sonra üretilmekte, başlangıçta bir yükselmeden sonra zaman içinde düzeyinin düşmesi pankreatitin düzelmekte olduğunu göstermektedir. Ne yazık ki bu test rutine henüz girememiştir. Diğer testlerin çoğu akut pankreatitte ek ölçütlerle birlikte kullanılmayı gerektirir ve kendi başlarina nonspesifiktirler. Methemalbüminin, sadece mortalite belirleyicisi olarak kullanılması halinde duyarlılı̆̆ının \%90'dan fazla olduğu gösterilmiş, mortalite kestirim gücünün Ranson ölçütlerinden fazla olduğu belirtilmiştir. Daha yakın zamanlarda monosit işlevlerini yansıtan göstergelerle ilgi çekici sonuçlar bildirilmiş $(39,40)$, ancak ağır akut pankreatitte nekrozektomi sonrasinda ek cerrahi gereğini yansıtamadığı görülmüştür. Gerek pankreas nekrozunun tek bir işlemle tanınması, gerekse tekrarlanan nekrozektomilere gereksinen ve/ya da nekrozektomi gereksiniminin sona erdiği hastalarin ayriminda nekroz spesifik belirleyicilerle daha çok sayıda klinik kestirim çalışmasına şiddetle gerek vardır.

7. Lechi A, Montesi G, Solbiati $M$ et al, Serum pancreatic enzyme alterastions in acute viral hepatitis, Hepatogastroenteroloy, 1983 ; 30:233-5.

8. Wilson JS Korsten MA, Lieber CS, Protein deficiency alters rat pancreatic lipid composition, JJ Nutr, 1986; 116:2055-8.

9. Ohnishi $H$, Kosuzume $H$, Ashida $Y$, Effects of urinary trypsin inhibitor on pancreatic enzymes and experimental acute pancreatitis Dig Dis Sci, 1984;29 :26-32.

10. Wilson JS, Korsten MA, Lieber CSS, New technique for the isolation of functional rat pancreatic mitochondra and its application to models of pancreatic injury, J Lab Clin Med. 1986 ; 107 : 51-8.

11. Hirano T, Manabe T, Fragility of subcellular organelles indued by pancreatic duct obstruction in rabbits, Nippon Geka Hokan, 1992 ; 61 : 334-49 (Medline Abstract).

12. Ranson JHC. Prognostic signs and the role of operative management in acute pancreatitis, Surg Gynec Obstet, 1974; 139:138. 
13. Rainson JHC, Etiologicall and prognostic factors in human acute pancreatitis: A review, $\mathbf{A m} J$ Gastroenterol, 1982; $9: 633-8$.

14. Gloor B. Late mortality in patients with severe acute pancreatitis. $\mathbb{B r}$ J Surg, 2001 ; 88 : 975-9.

15. Balthazar EJ, Traverso LW, Nukui Y, Kozarek RA. Computed tomography severity index is a predictor of outcomes for severe pancreatitis. Am J Surg. $1990 ; 174: 331-6$

16. Simcchuk EJ, Traveso LW-Nukui Y, Kozarek RA-Computed tomography severity index is a predictor of outcomes for severe pancreatitis. Am el Surg. $2002 ; 179: 352-5$.

17. Elmas $N$, The role of diagnostic radiology in pancreatitis. Eur Radiol, 2001; 38 120-32.

18. Munoz-Bongrand $N$, Serial computed tomography is rarely necessary in patients uith acute pancreatitis: A prospective study in 102 patients, J Am Col Sur, 2001; $193: 146-52$.

19. Takaccs $T$. Leukocyte scintigraphy in the diagnosis of acute pancreatitis, Orv Hetil, 1999; 28 $483-8$

20. Lankisch PG. Struckmann K, Lehnick D, Presene and extent of extrapancreatic fluid collections are predictors of severe acute pancreatitis, Int J Pan. creatol, $1999 ; 26: 131-6$.

21. Ertekin C, Kemertaş K, Günay K, Güloğlu R. Akut Pankreatit, Ulusal Travma Derg, 1995; 1 : 14-21.

22. Parodi HC, Value of laboratory tests and echograpy in the diagnosis of bilary disease in the inital phase of acute pancreatitis, Acta Gastroenterol Latinoam, 1990;20:137-44.

23. Kalfarentos $F E$, Treatment of patients with severe acute necrotizing pancreatitis based on prospective evaluation, Hepatogastroenterol. 1999; 46 : $3249-56$

24. Bradley EL III, Surgical treatment of acute pancreatitis: Indications and goals AGA Postgraduate Course, New Orleans. 1998.

25. Runkel NS-Rodriguez LF, Moody FG, Mechanisms of sepsis in acute pancreatitis in opossums. Am J Surg, $1995 ; 169: 227-32$.

26. Schoenberg MH, Rau B, Beger HG, New approaches in surgical management of severe acute pancreatitis Digestino, 1999;60 Suppl 1:22-6.

27. Nordback I, Sand. J, Saaaristo R, Paaajannen $H$, Early treatment with antibiotics reduces the need for surgery in acute necrotizing pancreatitis -A single center randomized study, J Gastrenterol Surg, 2001 ; $5: 113-20$

28. Gloor B, Pancreatic in severe pancreatitis: The role of fungus and multiresistant organisms, Arch Surg, $2000 ; 136: 592-6$.
29. Burcler MW, Acute necrotizing pancreatitis: Treatment strategy according to the status of infection, Ann Surg, 2000; $232: 627-9$.

30. McFadden DW, Reber Ha, Indications for surgery in severe acute pancreatitis, Int I Pancreatol, $1994 ; 15: 83-90$.

31. Beger HG-Uhl W, Berger D, Surgical therapy of acute pancreatitis, Helv. Chir Acta, 1992 ; 59 : 4760 .

32. Becher $P$, Reber HA, Surgical approach in patients with cute pancreatitis, Gastroenterol Clin North Am, $1999 ; 28: 6661-71$.

33. Wyncol DL, The management of severe acute necrotizing pancreatitis: An evidence based review of the literature, Intensive Care Med. 1999 ; 25 : 14656 .

34. Mor E, Delayed operation for acute pancreatitis, Isr eJ Med Sci. $1992 ; 28$ : 779-82 (Medline Abstract).

35. Lau St, Simchuk EJ Kozarek RA, Traverso $L W$, A pancreatic ductal leak should be sought to direct treatment in patients with acute pancreatitis, Am J Surg. 2001; $181: 411-5$.

36. Kasperk R, Riesener KP, Schumpelick V, Surgical thrapy of severe acute pancreatitis: A flexible approach gives excellent results. He. patogastroenterology. $1999 ; 46: 467-71$.

37. Banks PA, Controversies in the management of infected necrosis, AGA Postgraduate Course, New Orleans, 1998.

38. Rasslan S, Severe acute pancreatitis laparotomies and planned reoperation, Rev Paul Med, 1990 ; 108 : 169-73 (Medline Abstract)

39. Şakrak Ö, Bedirli A, Keçeli $M$, Ince Ö, Nekrotizan pankreatitli hastalarda nekrozektomi sonuçlartmı. Ulusal Cer Derg. 2000 ; 16 :162.9.

40. Norman JG, Cytokine mediators of acute pancreatitis: Potential new targets for pharmacologic therap, AGA Postgraduate Course, New Orleans, 1998.

41. Norman JG, Active Interleukin-1 receptor required for maximal progression of acute pancreatitis, Ann Surg. $1996 ; 223: 163-9$.

42. Kazmierczak, Biochemical indicators of acute pancreatitis, Clinical Pathology of Pancreatic Disorders (John A. Lott-Editor), Humana Press, New Jersey, $1997 ; 75-124$.

43. Rau B, et al. Clinical relevance of caspase-1 activated cytokines in acute pancreatitis, Crit Care Med, 2001; $29: 1556-62$.

44. Ricter A. HLA-DR expression in acute pancreatitis, Eur J Surg. 1999; 165: 947-51.

45. Gotzinger $P$, Severe acute pancreatitis acuses alteratinos in HLR-DA and CD14 expression on peripheral blood monocytes independently of surgical treatment. Eur eJ Surg. 2000; 166 : 628-32. 